\title{
Ice nuclei properties within a Saharan dust event at the Jungfraujoch in the Swiss Alps
}

\author{
C. Chou ${ }^{1}$, O. Stetzer ${ }^{1}$, E. Weingartner ${ }^{2}$, Z. Jurányi ${ }^{2}$, Z. A. Kanji ${ }^{1}$, and U. Lohmann ${ }^{1}$ \\ ${ }^{1}$ ETH Zurich, Institute for Atmospheric and Climate Science, Zurich, Switzerland \\ ${ }^{2}$ Laboratory of Atmospheric Chemistry, Paul Scherrer Institut, Villigen PSI, Switzerland
}

Received: 7 September 2010 - Published in Atmos. Chem. Phys. Discuss.: 12 October 2010

Revised: 13 May 2011 - Accepted: 16 May 2011 - Published: 20 May 2011

\begin{abstract}
The new portable ice nucleation chamber (PINC) developed by the Institute for Atmospheric and Climate Sciences of ETH Zurich was operated during two measurement campaigns at the high alpine research station Jungfraujoch situated at $3580 \mathrm{~m}$ a.s.1, in March and June 2009. During this time of the year, a high probability of Saharan dust events (SDE) at the Jungfraujoch has been observed. We used an impactor with a cutoff size of $1 \mu \mathrm{m}$ aerodynamic diameter and operated the system at $-31^{\circ} \mathrm{C}$ and relative humidities of $127 \%$ and $91 \%$ with respect to ice and water, respectively. Investigation of the ambient number concentration of ice nuclei (IN) in the deposition nucleation mode and during a SDE in the free troposphere is reported. The results discussed in this paper are the first continuous IN measurements over a period of several days at the Jungfraujoch. The average IN concentration found during the campaign in March was 8 particles per liter whereas during the campaign in June, the average number concentration was higher up to 14 particles per liter. Two SDEs were detected on 15 and 16 June 2009. Our measurements show that the SDEs had IN number concentration up to several hundreds per liter. We found the best correlation between the number concentration of the larger particle fraction measured by an optical particle counter and the IN number concentration during a Saharan dust event. This correlation factor is higher for particles larger than $0.5 \mu \mathrm{m}$ meaning that a higher concentration of larger particles induced higher IN number concentration. No correlation could be found between the black carbon mass concentration and the variations in IN number concentration.
\end{abstract}

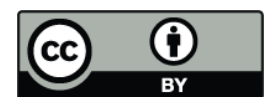

Correspondence to: C. Chou (cedric.chou@env.ethz.ch)

\section{Introduction}

Atmospheric aerosols contribute to the largest uncertainty in the global radiative forcing since pre-industrial times (Forster et al., 2007). On one hand aerosols have the ability to scatter and/or absorb the incoming solar and terrestrial radiation (aerosol direct effect), e.g Haywood and Boucher (2000). On the other hand, aerosols play a major role in the formation of clouds, and govern their lifetime as well as their microphysical properties influencing the precipitation and also the radiative budget (aerosol indirect effect), e.g., Lohmann and Feichter (2005). The ice phase in mixed-phase clouds is of crucial importance, as $30 \%$ of the tropical rain forms via the ice phase (Lau and $\mathrm{Wu}, 2003$ ). Ice crystals in the atmosphere form via two pathways: homogeneous and heterogeneous nucleation. Homogeneous nucleation is significant at temperatures below $-38^{\circ} \mathrm{C}$. At higher temperatures the formation of ice in clouds is triggered by heterogeneous nucleation which is divided into four sub-processes: Immersion, condensation, contact and deposition nucleation (Vali, 1985). Many laboratory studies as for example Mason and Maybank (1958); Isono et al. (1959); Roberts and Hallett (1968); Schaller and Fukuta (1979); Pruppacher and Klett (1997); DeMott (2002); Zuberi et al. (2002); Archuleta et al. (2005); Mangold et al. (2005); Kanji and Abbatt (2006); Knopf and Koop (2006); Möhler et al. (2006); Marcolli et al. (2007); Eastwood et al. (2008); Welti et al. (2009); Kulkarni and Dobbie (2010) have shown that mineral dust is a good ice nucleus (IN) in both immersion and deposition nucleation mode and usually initiate nucleation at rather high temperatures and low relative humidities. This statement is supported by field studies (DeMott et al., 2003b; Richardson et al., 2007; Klein et al., 2010) where high concentrations of mineral dust led to a significant increase in the ice crystal number concentration. Previous studies by Vali et al. (1976);

Published by Copernicus Publications on behalf of the European Geosciences Union. 
Schnell and Vali (1976); Möhler et al. (2008) showed that bioaerosols and especially some specific bacteria like Pseudomonas Syringae initiate ice formation at warmer temperatures than mineral dust. Pratt et al. (2009) found that one third of the ice particle residues in one cloud collected by a Counterflow Virtual Impactor (CVI) at high altitude over Wyoming contained biological markers. Soot and particles containing black carbon (BC) are also known to act as IN, but require much lower temperatures and higher relative humidities for activation as compared to bioaerosols and mineral dust (DeMott et al., 1999; Dymarska et al., 2006). Dymarska et al. (2006) showed that in order to trigger deposition nucleation, soot require temperatures lower than $-30^{\circ} \mathrm{C}$ and relative humidity with respect to water close to saturation. Nevertheless Cozic et al. (2008a) found that ice residuals in mixed-phase clouds collected at the high alpine research station Jungfraujoch (JFJ) in Switzerland have a BC mass enrichment of $27 \%$. As the temperature at the station is never lower than $-30^{\circ} \mathrm{C}$, these measurements raise some questions: do BC particles form ice mainly via immersion or/and contact freezing at the Jungfraujoch? Do these BC particles have different properties than those produced in laboratory and have enhanced IN properties in the deposition mode? The ice nucleation properties of BC are still unclear as a recent study conducted by Kamphus et al. (2010) at the JFJ during the Cloud and Aerosol Characterization Experiment 6 (CLACE-6) showed no enrichment of BC in the particles analyzed.

So far, very few studies with chambers have been performed in-situ in the free or upper troposphere, where conditions are favorable for the formation of mixed-phase and ice clouds. Those studies are summarized in Möhler et al. (2007) and showed that the IN number concentration could vary from 0.01 to 50 particles per liter for different regions, seasons and altitude. In order to have additional data at different locations in the world and information on IN properties of atmospherically relevant aerosols, two measurement campaigns were conducted at the JFJ in March and June 2009. A previous study has been conducted at the JFJ in order to characterize ice crystals sampled in mixed-phase clouds (Mertes et al., 2007). They found during CLACE-3 an average concentration of several hundreds ice residuals per liter in one cloud on 24 March 2004 using an ice-CVI. Our measurement campaigns were also motivated by the high probability of Saharan Dust Events (SDE) between March and June (Collaud Coen et al., 2004). This paper shows the first dataset of IN measurements at the JFJ over several days and discusses results of IN number concentration and its variation with respect to a SDE at the JFJ. Correlation between BC and IN concentrations are also discussed.

\section{Experimental setup}

\subsection{Ice nuclei measurements}

\subsubsection{The portable ice nucleation chamber}

The Portable Ice Nucleation Chamber (PINC) has recently been developed in order to measure IN concentrations during airborne and field campaigns. It is the portable version of the Zurich Ice Nucleation Chamber (ZINC) (Stetzer et al., 2008) and its principle follows the Continuous Flow Diffusion Chamber (CFDC) of the Colorado State University (Rogers, 1988). Briefly, it consists of two flat parallel plate walls which can be cooled independently of each other to temperatures as low as $-47^{\circ} \mathrm{C}$ for the warm side and $-55^{\circ} \mathrm{C}$ for the cold side. Before a measurement, the chamber is flooded with water for a short period in order to produce a thin ice layer on the walls which then is maintaining a constant relative humidity of ice saturation on the wall surface. By applying a temperature difference between both walls, diffusion of water vapor leads to a supersaturation within the chamber which depends on the position between the walls and the temperature gradient. A continuous flow of sample air, typically 1 liter per minute (lpm) - layered between two particle-free sheath flows, typically $4.5 \mathrm{lpm}$ each - is drawn through the chamber to expose the sample to a defined supersaturation and temperature for a duration of about $7 \mathrm{~s}$. It is important to mention that PINC can only measure in the deposition and condensation nucleation modes and to some extent in the homogeneous freezing mode. The major differences between our established lab-instrument ZINC and the new PINC instrument are the portable and lightweight cooling system and the reduced chamber length so that the instrument fits into existing research aircraft. Table 1 summarizes some of the main differences between PINC and ZINC. The cooling system of PINC consists of two independent compressor-based refrigeration systems where the evaporation tubes made out of copper are firmly inserted into drilled channels on the outer sides of the chamber walls. Because a measurement requires a temperature gradient between the walls, the two systems are not identical. Hence, the cooling system for the warmer wall consists of two parallel compressors (BD120, Danfoss) while the colder wall system has in total 5 compressors of the same kind, but connected in a $4+1$ manner, meaning 4 parallel units combined with one further in series to obtain a higher compression to reach lower temperatures. More details are shown in Fig. 1. The BD120 compressors were chosen because they are specially made for mobile applications. They run of 24 Volts DC and their cooling power can be regulated over a wide range with pulsewidth-modulation (PWM) drivers. They also tolerate tilting of the instrument while in operation and are therefore well suited for airborne instruments.

In laboratory tests, we reached sampling conditions of $-45^{\circ} \mathrm{C}$ with a relative humidity with respect to ice $\left(\mathrm{RH}_{\mathrm{i}}\right)$ of 
Table 1. Summary of PINC and ZINC characteristics

\begin{tabular}{lcr}
\hline Parameters & PINC & ZINC \\
\hline Main chamber size & $568 \times 300 \mathrm{~mm}$ & $1000 \times 300 \mathrm{~mm}$ \\
Evaporation section length & $230 \mathrm{~mm}$ & $750 \mathrm{~mm}$ \\
Residence time in main chamber & $7 \mathrm{~s}$ & $12 \mathrm{~s}$ \\
Residence time in evaporation section & $2 \mathrm{~s}$ & $8 \mathrm{~s}$ \\
Operating conditions & down to $-65^{\circ} \mathrm{C}$ & down to $-40^{\circ} \mathrm{C}$ \\
Ice coating thickness & $550 \mu \mathrm{m}$ & $600 \mu \mathrm{m}$ \\
Icing time & $45 \mathrm{~s}$ & $90 \mathrm{~s}$ \\
\hline
\end{tabular}
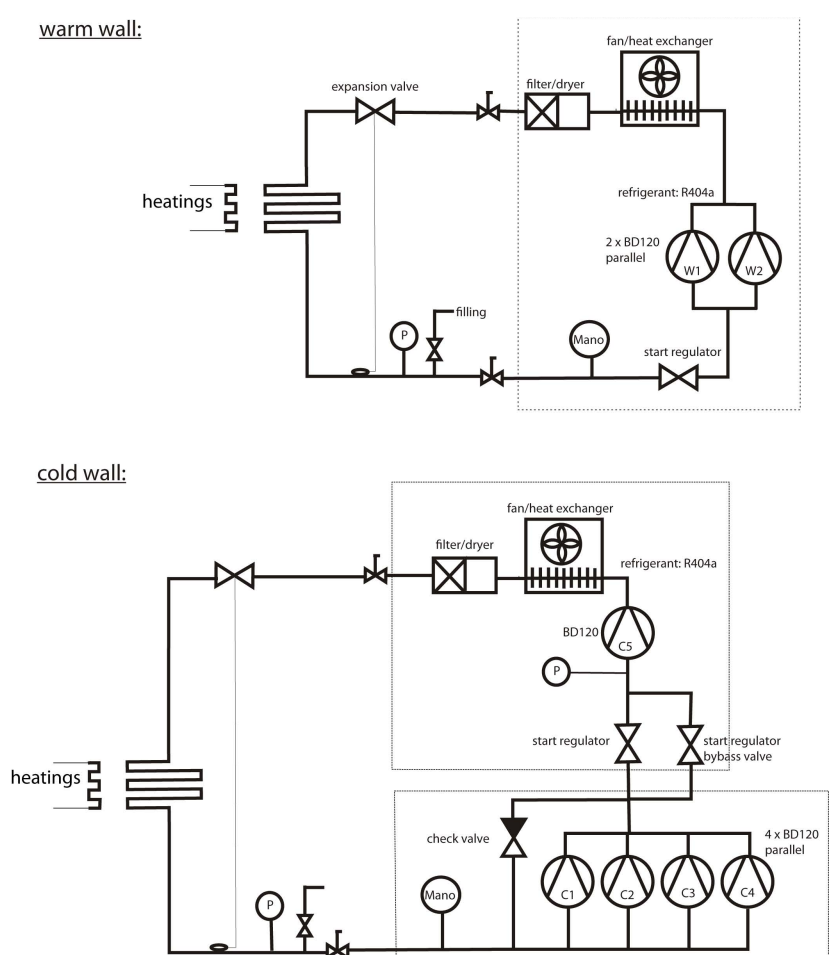

Fig. 1. Schematic of the cooling system in PINC.

$158 \%$ and a relative humidity with respect to water $\left(\mathrm{RH}_{\mathrm{w}}\right)$ of $100 \%$. At these conditions, the wall temperatures are at $-51^{\circ} \mathrm{C}$ and $-33{ }^{\circ} \mathrm{C}$ for the cold and the warm wall, respectively. In parallel to the evaporation tubes, several heating pads are attached to each wall which help when positive temperature changes are needed for one wall and to compensate for possible temperature inhomogeneities within a wall. Furthermore, those heating pads support the regulation of the compressor power as these cannot be operated below $40 \%$ of their maximum cooling power. In these regions, a combination of cooling and heating is needed.

The instrument has a short isothermal evaporation section attached at the bottom of the main chamber, which is cooled by the warm wall cooling system and thus is maintained at the warm wall temperature, allowing the section to be satu-
Table 2. Conversion table from Stokes to aerodynamic diameter following Baron and Willeke (2001) and assuming an average particle density of $1.5 \mathrm{~g} / \mathrm{cm}^{3}$ (Cozic et al., 2008b) and a density of $2.3 \mathrm{~g} / \mathrm{cm}^{3}$, representative of mineral dust average density. We assume a dynamic shape factor of 1 and that the optical diameter is equivalent to the Stokes diameter.

\begin{tabular}{lcr}
\hline $\begin{array}{l}\text { Optical diameter } \\
(\mu \mathrm{m})\end{array}$ & $\begin{array}{r}\text { aerodynamic diameter } \\
(\mu \mathrm{m}) / 1.5 \mathrm{~g} \mathrm{~cm}^{-3}\end{array}$ & $\begin{array}{r}\text { aerodynamic diameter } \\
(\mu \mathrm{m}) / 2.3 \mathrm{~g} \mathrm{~cm}^{-3}\end{array}$ \\
\hline 0.3 & 0.367 & 0.455 \\
0.4 & 0.49 & 0.607 \\
0.5 & 0.612 & 0.758 \\
0.6 & 0.735 & 0.91 \\
0.65 & 0.796 & 0.986 \\
0.74 & 0.91 & 1.127 \\
0.8 & 0.98 & 1.213 \\
1.0 & 1.225 & 1.517 \\
\hline
\end{tabular}

rated with respect to ice but subsaturated with respect to water. Thus, the section allows evaporation of droplets which may form at/or above water saturation so that they are not falsely counted as ice crystals by the optical particle counter (OPC) (Climet, OI 3100). The residence time of a particle in this section is $2 \mathrm{~s}$ and depending on the evaporation section temperature, droplets will evaporate slower or faster. Figure 2 shows the maximum $\mathrm{RH}_{\mathrm{w}}$ we can reach before water droplets formed inside the chamber can survive and be falsely counted as ice crystals by the OPC. The data acquisition system of PINC is similar to the one of ZINC (Stetzer et al., 2008) but uses the more up-to-date CRIO architecture (National Instruments). This consist of a real-time computer running a specialized version of the Labview programming language. It also has a FPGA (field programmable gate array) chip to implement certain parts of the code which directly reads from input and writes to output modules in hardware. Code on the FPGA is very fast and efficient. We take advantage of this by using simple high-current digital output modules to regulate the power of heatings and compressors with software PWM drivers which are running inside the FPGA chip. 


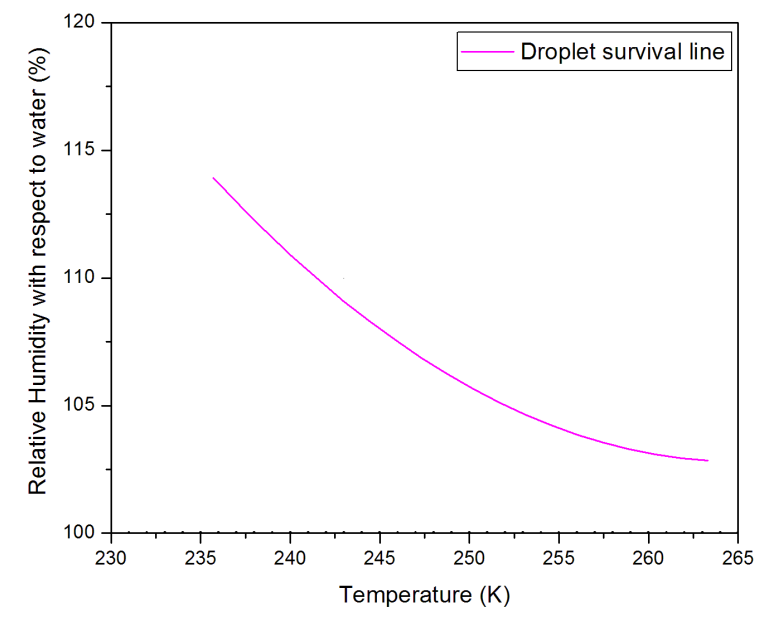

Fig. 2. Experimental determination of the water droplet survival line (water breakthrough) for different temperatures. Above the droplet survival line, the OPC can not distinguish ice crystals and water droplets.

\subsubsection{Large particles and wet particles issues}

The current setup of PINC uses an OPC to detect ice crystals by size. A particle is classified as ice crystal by the OPC when its optical diameter is larger than $3 \mu \mathrm{m}$. Since PINC has been designed for field and in-situ measurements, the presence of large particles as well as water droplets cannot be excluded.

In order to remove the large particle fraction, we used the impactor built for the Differential Mobility Analyser (DMA) from TSI with an orifice of $0.071 \mathrm{~cm}$. Several laboratory tests with an Aerodynamic Particle Sizer (APS) (TSI, model 3321) and a Scanning Mobility Particle Sizer (SMPS) (TSI, model 3080) sampling ambient air have been performed and Fig. 3 shows the impactor efficiency for different aerodynamic sizes. The cutoff d50 is at $0.91 \mu \mathrm{m}$, aerodynamic diameter. Table 2 shows the conversion between aerodynamic and Stokes diameter following Baron and Willeke (2001) (see Eq. 1):

$d_{\mathrm{a}}=d_{\mathrm{p}} \cdot\left(\frac{\rho_{\mathrm{p}}}{\chi \cdot \rho_{0}}\right)^{\frac{1}{2}}$,

with $d_{\mathrm{a}}$ the aerodynamic diameter, $d_{\mathrm{p}}$ the diameter of a spherical particle, $\rho_{\mathrm{p}}$ the particles density, $\rho_{0}$ the standard density of a spherical particle, typically $1 \mathrm{~g} / \mathrm{cm}^{3}$ and $\chi$ the dynamic shape factor. We assume that the optical diameter is equivalent to the Stokes diameter. Cozic et al. (2008b) showed that the submicron particle average density at the JFJ was $1.5 \mathrm{~g} / \mathrm{cm}^{3}$, which is one of the values we use for the conversion in Table 2. According to Kaaden et al. (2008) the dynamic shape factor of Saharan dust is 1 for particles smaller than $0.55 \mu \mathrm{m}$ and in the order of 1.2 for particles of $1 \mu \mathrm{m}$. This leads to an error of $10 \%$ on the largest particle size sampled during our campaigns.

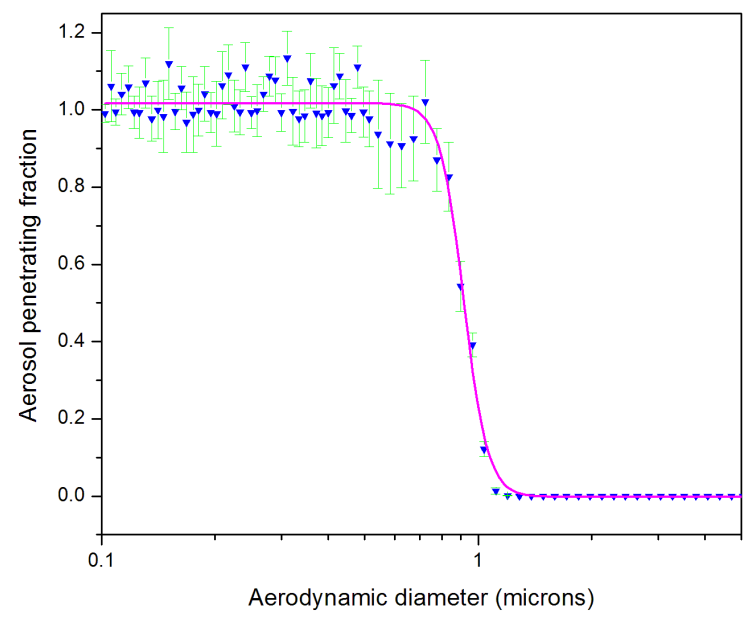

Fig. 3. Aerosol penetrating fraction of the impactor used. Note the sharp cut-off at $1 \mu \mathrm{m}$ aerodynamic diameter. The magenta curve is the sigmoid fit of the blue data points. Green error bars represent the standard deviation of the measurements.

The main objective of this study is to focus on the deposition nucleation mode, so it is crucial that the particles sampled are dry. In order to do so, we use a molecular sieve diffusion drier mounted in front of the system. The relative humidity measured at the exit of the diffusion drier is $1 \%$ (with a sensor accuracy of $\pm 2 \%$ ), which is sufficient to remove the moisture from the particles. The particle gravitational loss is $2 \%$ for the larger size sampled i.e. $1 \mu \mathrm{m}$, and the diffusion loss for the smallest particles we expect to be IN $(0.1 \mu \mathrm{m})$ is below $1 \%$.

\subsubsection{Validation experiments using ammonium sulphate aerosol}

The sample temperature and relative humidities are calculated from the measured temperatures of the main chamber walls. In order to validate the accuracy of the calculated temperature and relative humidities at the sample position inside the chamber, the deliquescence and freezing points of ammonium sulphate (AS) aerosols were investigated at different thermodynamic conditions, because they are well known from the literature. Ammonium sulphate particles were produced from a $3 \%$ (by weight) AS solution which was then atomized. The droplets went through a molecular sieves diffusion drier to crystallize the droplets. The particles were then size selected with the DMA attached to the SMPS before entering PINC. Validation experiments were performed with $200 \mathrm{~nm}$ particles at two temperatures, $-30^{\circ} \mathrm{C}$ and $-40^{\circ} \mathrm{C}$. The experiments at $-30^{\circ} \mathrm{C}$ showed deliquescence of the particles at $84 \% \mathrm{RH}_{\mathrm{w}}$ at the sample position which is in good agreement by $\pm 2 \%$ with the values obtained by Braban et al. (2001) and Kanji and Abbatt (2006). In order to see at which conditions AS could freeze homogeneously, we operate the chamber at $-40^{\circ} \mathrm{C}$ which is below the temperature 
of homogeneous freezing, and set a $\mathrm{RH}_{\mathrm{w}}$ above the deliquescence point of AS. We found that AS froze homogeneously at relative humidities of $145 \%$ and $97 \%$ with respect to ice and water, respectively. These values also agree by $\pm 2 \%$ with the theoritical values calculated by Koop et al. (2000) based on the water activity for a $200 \mathrm{~nm}$ diameter aerosol particle.

\subsubsection{Operating conditions during the two measurement campaigns}

IN number concentration measurements took place from 24 February to 10 March 2009 and from 3 to 17 June 2009 at the JFJ research station situated at an altitude $3580 \mathrm{~m}$ a.s.1 $\left(46^{\circ} 33^{\prime} \mathrm{N}\right.$ by $\left.7^{\circ} 59^{\prime} \mathrm{E}\right)$. The $\mathrm{JFJ}$ is mostly in free tropospheric conditions and is a Global Atmosphere Watch (GAW) station where aerosols and gases have been measured for several years. Further description of the measurement site are given in Baltensperger et al. (1997).

Kanji and Abbatt (2006) showed that at $-30^{\circ} \mathrm{C}$, the nucleation onset of Saharan dust was below a $\mathrm{RH}_{\mathrm{i}}$ of $110 \%$ in the deposition mode. Thus in order to activate any possible Saharan dust present at the JFJ, the operating conditions of PINC during this campaign at the sample position were set to $-31{ }^{\circ} \mathrm{C}$ (which is a relevant temperature for mixed-phase clouds), with a $\mathrm{RH}_{\mathrm{i}}$ of $127 \%\left(\mathrm{RH}_{\mathrm{w}}=91 \%\right)$. Every measurement point reported in Figs. 4, 7,11 and 12 is a $15 \mathrm{~min}$ average, with a five second interval between each IN count. Due to background signal coming from the chamber, a blank measurement of $5 \mathrm{~min}$ (no aerosol injected) at the beginning and at the end of a measurement is taken in order to obtain an average background value that can be substracted from the $15 \mathrm{~min}$ average measurement. This background signal is coming from ice peaks that have grown and break-off from the walls of the chamber, and is typically less than 3 particles per liter. We usually re-ice the chamber after 2 and a half hours of ambient measurements, when the background signal exceeds 5 particles per liter and that the sampled IN values are not high enough as compared to the chamber background values. In some cases IN measurements are shown even if the background exceeded 5 particles per liter but the sampled IN were then at least two times higher than the background signal.

\subsection{Black carbon measurements}

Downstream of the total aerosol inlet, a Multi-Angle Absorption Photometer (MAAP, Thermo ESM, Andersen) operated at a nominal wavelength of $\lambda=630 \mathrm{~nm}$ (Petzold and Schönlinner, 2004) was used to measure in real time the light absorption coefficient $b_{\text {abs }}$. BC particles are the most effective atmospheric light absorbing aerosol species in the visual spectral range and therefore this parameter is used in order to derive the $\mathrm{BC}$ mass concentration $\left(\mathrm{g} / \mathrm{m}^{3}\right)$ following Eq. (2):

$b_{\mathrm{abs}}=\sigma_{\mathrm{abs}, \mathrm{BC}} \cdot \mathrm{BC}$,

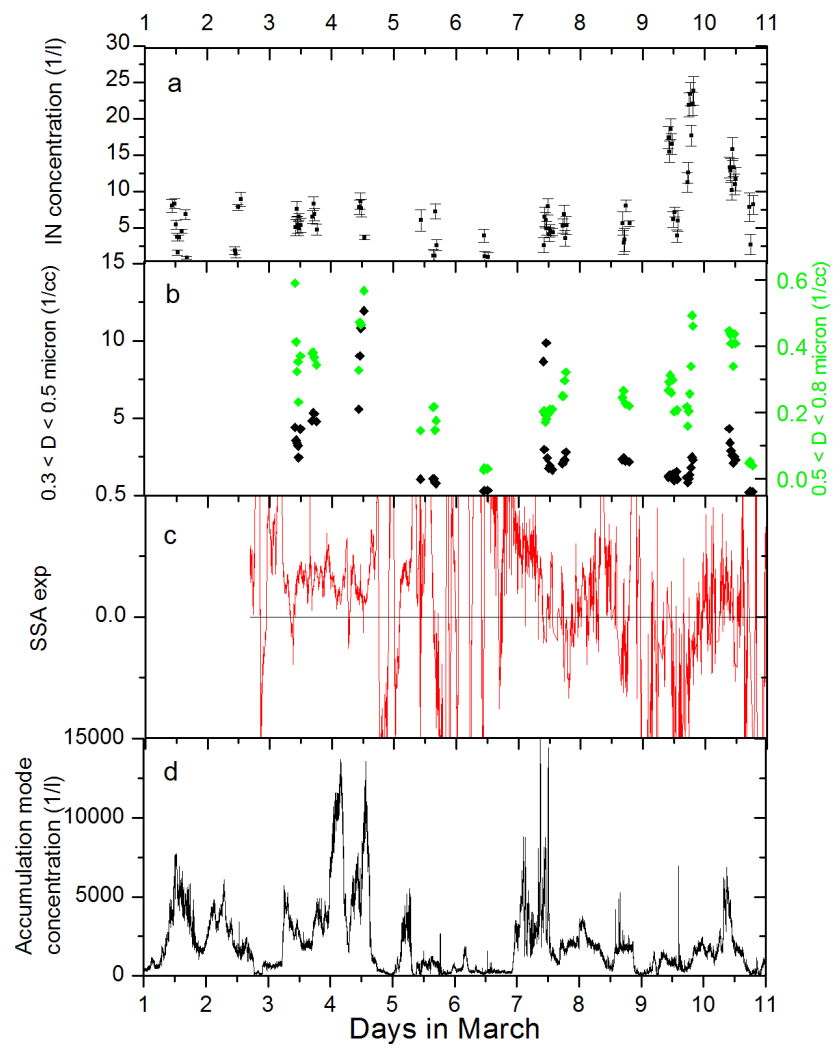

Fig. 4. Panel (a): Time series of the 15 minutes IN average number concentration (particles/liter) from 1 to 11 March 2009. Panel (b): Particles concentration per size class. Panel (c): Single Scattering Albedo (SSA) exponent value. Panel (d): Particles number concentration in the accumulation mode.

where $\sigma_{\mathrm{abs}, \mathrm{BC}}\left(\mathrm{m}^{2} / \mathrm{g}\right)$ is the mass absorption efficiency set to $6.6 \mathrm{~m}^{2} / \mathrm{g}$. Both $\sigma_{\mathrm{abs}, \mathrm{BC}}$ and $b_{\mathrm{abs}}$ are wavelength dependent. The measurements were performed with a 1 min time resolution and ran for $24 \mathrm{~h}$. Cozic et al. (2007) have made a comparison with another MAAP instrument running behind a $\mathrm{PM}_{2}$ inlet and found a very high correlation of $R^{2}=0.97$ and a slope of 0.95 which indicates that most of the BC mass is found below a diameter of $2 \mu \mathrm{m}$.

It is important to mention that hematite which could be found in mineral dust is another compound that can significantly absorbs light. It usually has a small contribution to the total absorption coefficient in pristine days, but significantly changes the absorption coefficient when high dust load are present (Collaud Coen et al., 2004). Further information about $\sigma_{\mathrm{abs}, \mathrm{BC}}$ measurements with the MAAP at the Jungfraujoch can be found in Cozic et al. (2008b).

\subsection{Detection of Saharan dust events}

The dry particle scattering coefficient $\sigma_{\mathrm{sp}}$ was measured by an integrated nephelometer (IN, TSI 3563) simultaneously at three different wavelengths $(\lambda=450,550$ and $700 \mathrm{~nm})$. 

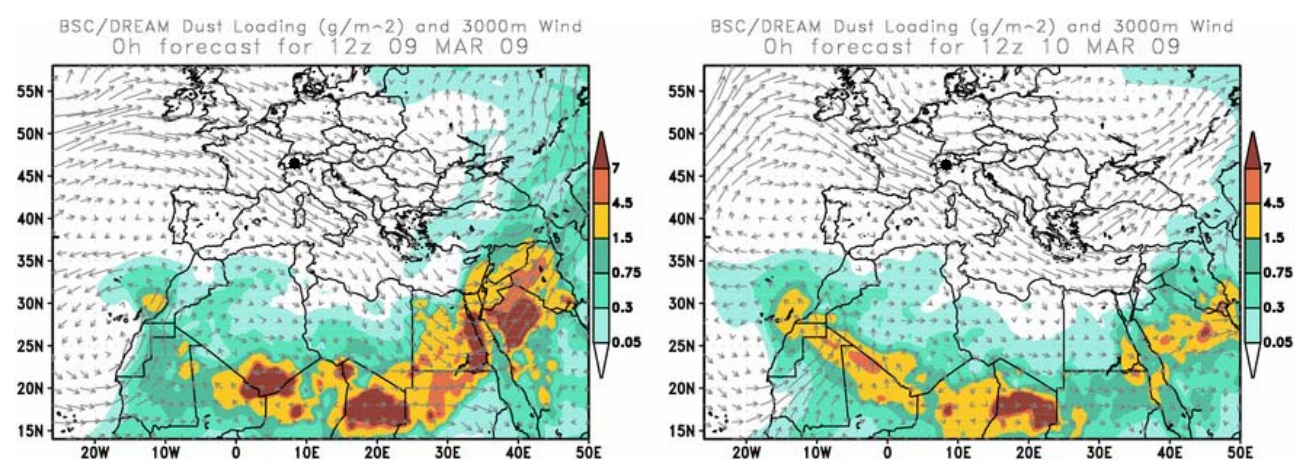

Fig. 5. Dust load distribution over the Mediterranean region on 9 and 10 March 2009 at 12:00 p.m. UTC. The black dot marks the location of the Jungfraujoch.
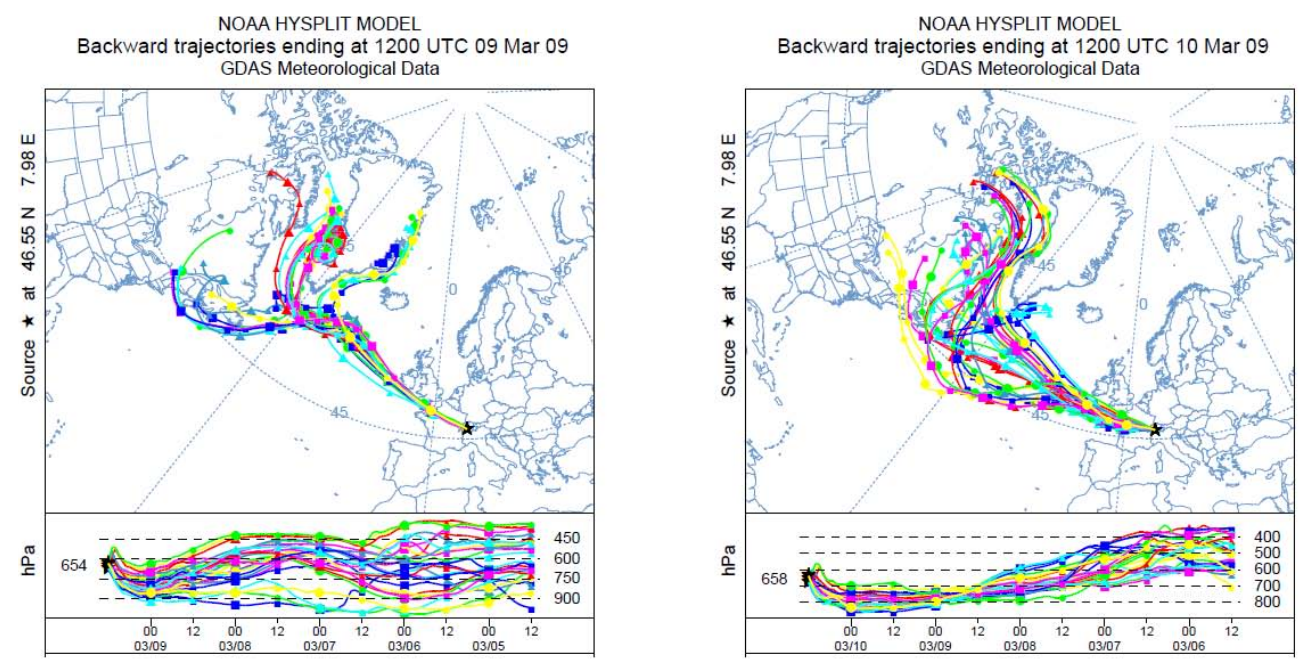

Fig. 6. Four days backtrajectories on 9 and 10 March 2009 at Jungfraujoch at 12:00 p.m. UTC.

The data are collected with a five minutes resolution and an hourly average was calculated from these data. The absorption coefficient $\sigma_{\text {ap }}$ was measured by an aethalometer (AE31, Magee Scientific) at seven wavelengths $(\lambda=370,470$, $520,590,660,880$ and $950 \mathrm{~nm}$ ). The calculation of $\sigma_{\text {ap }}$ was done following Weingartner et al. (2003).

The scattering and absorption coefficients are used to derive the single scattering albedo (SSA) exponent $\alpha_{\mathrm{SSA}}$, which describes the wavelength dependence of the SSA:

$\omega_{0}=b_{\mathrm{SSA}} \cdot \lambda^{-\alpha_{\mathrm{SSA}}}$,

where $\omega_{0}$ is the SSA, $b_{\text {SSA }}$ the SSA coefficient and $\lambda$ the wavelength. Notice that a dust event is notified only if the SSA exponent is negative for more than 4 hours consecutively. More details can be found in Collaud Coen et al. (2004).

These instruments were complemented by an optical particle counter (OPC, Grimm Dust monitor 1.108) measuring the dry particle size distribution in the diameter range of 0.3 to $20 \mu \mathrm{m}$ behind the total aerosol inlet. The factory calibration of the OPC was done with LATEX spheres. Schwikowski et al. (1995) found that there is an increase in the coarse fraction of the aerosol size distribution during a SDE, suggesting that an increase in the supermicron mode detected by the OPC is also a good indicator of dust load at the JFJ.

In order to predict a SDE we used the BSC-DREAM dust model forecast (Nickovic et al., 2001; Pérez et al., 2006a,b) from the Barcelona Supercomputing Center (BSC). Distribution of dust load around the Mediterranean region can be forecasted $72 \mathrm{~h}$ in advance, and wind profiles can also be observed. In complement, we used that tool in combination with the NOAA HYSPLIT trajectory and dispersion model (Draxler and Rolph, 2011; Rolph, 2011) to calculate backtrajectory ensembles arriving at the JFJ during the days of interest. This allow us to investigate the origin of air masses and to interpret our data. 


\section{Results and discussion}

\subsection{Ice nuclei number concentration}

\subsubsection{Average IN number concentration during both campaigns}

Due to some instrumentation problems, some days during both campaigns are not reported in the figures. IN number concentration in the deposition nucleation mode from 1 to 10 March are reported in Fig. 4 (panel a). The IN number concentration for the first 8 days is below 10 particles per liter, however there is an increase on 9 and 10 March. The IN number concentration during these two days reached 20 particles per liter. In order to trace a possible presence of dust that could cause this increase, backward trajectories have been calculated for these two days. Figure 6 shows the 4-day backtrajectories and Fig. 5 shows the dust load over Northern Africa and Europe. Both backward trajectories show no evidence of dust arriving at JFJ, meaning that the higher IN number concentration on these two days must have a different source.

The average IN number concentration of the measurement period in March is 8 particles per liter. In comparison, Mertes et al. (2007) found a number of ice residuals two orders of magnitude higher than our results. This can be explained by the fact that we are investigating only the deposition nucleation mode, neglecting immersion, condensation and contact freezing. Moreover, we have restricted our size range of particles sampled up to $1 \mu \mathrm{m}$ aerodynamic diameter. Finally, particles found in the ice residuals in their study could also be an effect of scavenged interstitial aerosols, and furthermore the ice residuals might have another origin meaning that they were not formed recently before being collected with the iceCVI.

In Fig. 7 (panel a), the IN number concentration from 10 to 16 June is shown. The average ambient IN number concentration (not influenced by SDEs) is around 14 particles per liter which is twice as high as at the beginning of March. Klein et al. (2010) has recently found a IN number concentration of about $40 \mathrm{IN}$ per liter at the Taunus observatory at a temperature of $-18^{\circ} \mathrm{C}$. It is important to mention that in their study, the particle size range sampled is from 0.2 to $12 \mu \mathrm{m}$ whereas we sampled particles with an upper size limit of $1 \mu \mathrm{m}$ aerodynamic diameter. Furthermore they might have a constant influence of the Planetary Boundary Layer (PBL), which contributes to a higher number of particles, meaning more potential IN. As another comparison, Richardson et al. (2007) using a CFDC found IN number concentration varying from 1 to 10 IN per liter during Spring at the Storm Peak Laboratory (SPL) situated in the Rocky Mountains of northwestern Colorado (USA). The SPL is located at $3210 \mathrm{~m}$ above mean sea level (m.s.l.) and is comparable to the altitude of the Jungfraujoch. The average IN number concentration found during our campaigns are in good agreement with

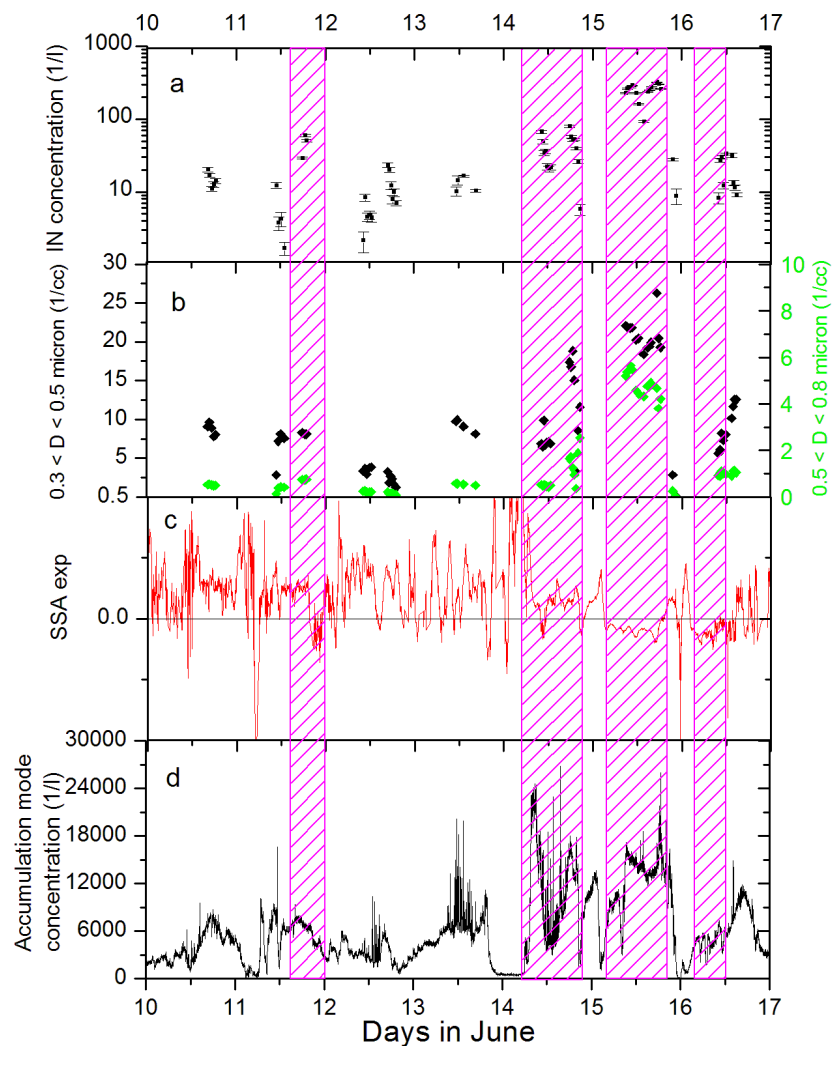

Fig. 7. As Fig. 4 but from 10 to 16 June 2009. The magenta shaded area represents period with high IN number concentration and which could be attributed to Saharan dust contribution.

their results at the same thermodynamic conditions. Higher concentrations ( $>25$ IN/liter) could be observed on four different days, 11, 14, 15 and 16 June. These are discussed in the following sections.

\subsubsection{High IN number concentration events}

Two SDE were detected on 15 and 16 June (see Fig. 7) by optical means according to the methodology discussed in Sect. 2.3 and used by Collaud Coen et al. (2004) to assess the presence of SDE. The presence of Saharan Dust was confirmed by backtrajectories shown in Fig. 10. The IN number concentration increased by 10 to 20 times compared to typical IN concentrations. This result is in good agreement with the results from DeMott et al. (2003b) who found a significant increase in IN number concentration of 20 to 100 times when they sampled within transported African dust layers over Florida. Note that the operating temperature was $5^{\circ} \mathrm{C}$ higher than that of the CFDC during the DeMott et al. (2003b) study. Note also that the IN number concentration during a SDE during our study would have probably been higher if our setup would have allowed measurements of larger particles. Figure 8 shows that the fraction of dust is present above $0.6 \mu \mathrm{m}$ and it has been shown for mineral dust 


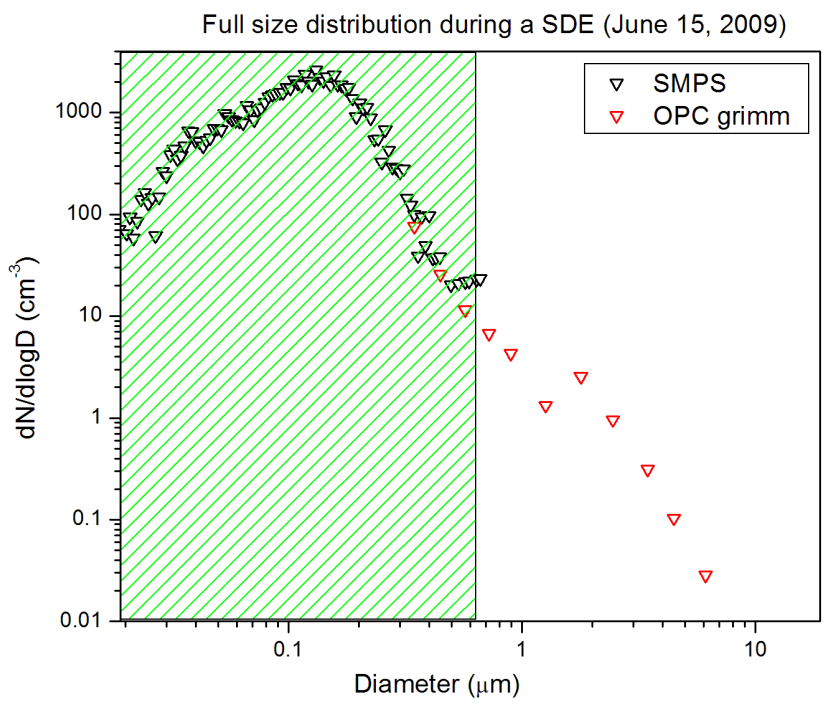

Fig. 8. Full size distribution during a Saharan Dust Event on 15 June 2009. The green shaded area corresponds to the fraction of particles sampled through PINC within a SDE.

that the larger, the better IN (Archuleta et al., 2005). This high increase in IN number concentration is also in very good agreement with the recent study by Klein et al. (2010) who found a concentration of IN 10 times higher than a typical day during a Saharan dust episode at the Taunus Observatory in Germany. On 16 June the IN number concentration is slightly higher than on a typical measurement day due to the SDE contribution, but is less intense than the one on 15 June. Therefore, we investigated the dust load shown in Fig. 9 and combined these information with the backward trajectories in order to trace the sources and concentration of the mineral dust. Figure 9 shows that on 15 June the air masses was coming from North Africa, where the dust concentration was high (around $0.75 \mathrm{~g} / \mathrm{m}^{2}$ ). On the other hand, on 16 June, air masses mainly came from the North Atlantic Ocean with a contribution from North West of Africa where a lower dust load was present $\left(<0.3 \mathrm{~g} / \mathrm{m}^{2}\right)$. This difference in the dust load mainly explains the differences in the concentration of ice crystals measured on these two days.

On 11 June in the late afternoon and on 14 June, higher IN number concentration were also observed although the SSA exponent was not negative. Figures 9 and 10 show that air masses on 14 June were coming from North Africa and contain high dust loads which explain the increase in IN number concentration on that day. In comparison with 15 June, the IN concentration is more irregular on 14 June. We observed a very high concentration in the morning followed by a decrease at noon. Then in the beginning of the afternoon, high IN concentration could be observed again followed by a steep drop in the evening. These variations in concentration at noon can be explained by the fact that during summer, the JFJ can be influenced by the PBL, therefore increasing the
Table 3. Linear regression correlation coefficient $R^{2}$, slope and offset for different cases

\begin{tabular}{lccr}
\hline Conditions & $R^{2}$ & slope & offset $\left(\mathrm{cm}^{-3}\right)$ \\
\hline size class: $0.3<D<0.5 \mu \mathrm{m}$ & & & \\
no dust $(94$ measurement points) & 0.03 & 0.0005 & 0.0098 \\
SDE (37 measurement points) & 0.75 & 0.01395 & -0.06473 \\
all days (131 measurement points) & 0.69 & 0.01006 & -0.0231 \\
size class: $0.5<D<0.8 \mu \mathrm{m}$ & & & \\
no dust & 0.12 & 0.02028 & 0.00647 \\
SDE & 0.82 & 0.07864 & 0.00322 \\
all days & 0.88 & 0.08123 & -0.00651 \\
\hline
\end{tabular}

aerosol number concentration in the accumulation mode for a short period if the PBL is oscillating around the altitude of the research station. Note that investigating the number concentration of the accumulation mode is a good indicator of the PBL influence (Nyeki et al., 1998).

This is supported by data shown in Fig. 7 (panel d), where we observe oscillation in the accumulation mode concentration with a maximum in the morning, followed by a steep decrease at noon. Then, an increase in the early afternoon is followed by a decrease towards the evening. These oscillations in dust concentrations can also explain why the SDE on 14 June was not detected by optical means. As described in Sect. 2.3, a SDE is considered to occur only if the SSA exponent is negative for at least four hours consecutively. On 11 June, the air masses arriving at the JFJ did not contain any dust according to Figs 9 and 10, but a sudden increase could be observed at around 5:00 p.m., for a short time. Due to the lack of real time instrumentation to characterize the chemical composition of the particles, we cannot conclude in this case, that a dust event was present at the site, but the hypothesis of dust contribution transported over the North Atlantic Ocean should not be excluded.

\subsection{Atmospheric implications}

The effects of high concentration of mineral dust in the atmosphere on the formation of clouds have been reported in Sassen (2002) and Sassen et al. (2003). Those studies showed that cirrus formation took place at temperatures significantly warmer than during clean conditions, inducing heterogeneous ice nucleation. The presence of higher IN number concentration at mixed phase cloud regimes contributes to faster precipitation of the cloud due to the BergeronFindeisen process and therefore reduces the cloud lifetime.

A high mineral dust concentration at cirrus level also leads to the competition between homogeneous and heterogeneous nucleation. This effect is discussed in Kärcher et al. (2006) who showed with their parameterization that at $230 \mathrm{~K}$ and for a constant updraft of $20 \mathrm{~cm} / \mathrm{s}$ through time, several hundreds of IN per liter can deplete the water vapor and totally prevent homogeneous nucleation to take place. This lowers the base of the cirrus clouds leading to more extensive cirrus clouds 

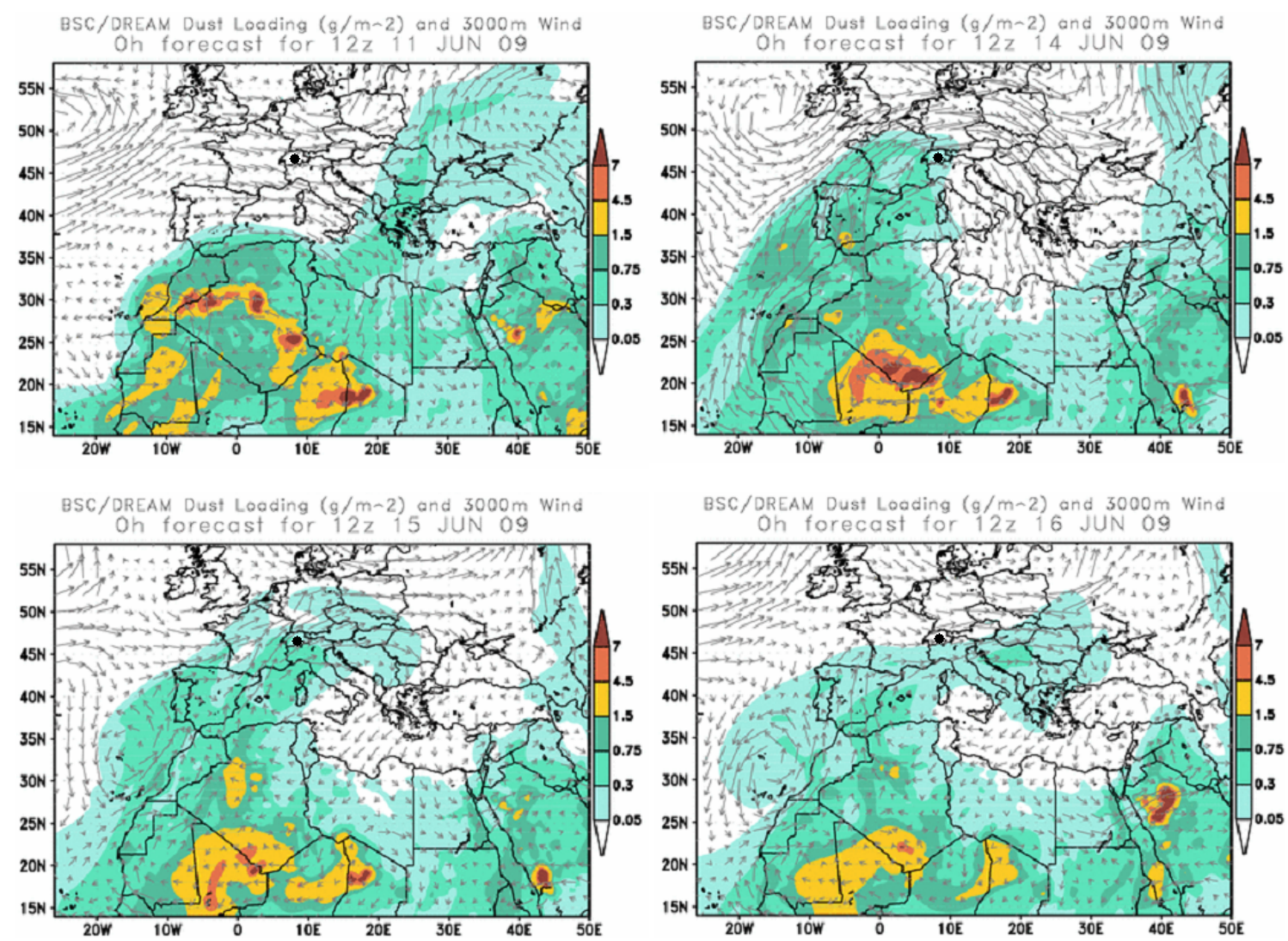

Fig. 9. Dust load distribution over the Mediterranean region on 11, 14, 15 and 16 June 2009 at 12:00 p.m. UTC. The black dot marks the location of the Jungfraujoch.

and a modified radiative forcing as well as different distribution of the relative humidity in the upper troposphere. This parameterization is not so realistic as it did not take sedimentation processes of grown ice crystals into consideration and the critical supersaturation for heterogeneous nucleation was set to the same value for different temperatures and IN sizes. In a more recent study from Spichtinger and Cziczo (2010), sedimentation processes as well as different critical supersaturation as a function of size have been included. The study shows the same results for even a lower IN concentration ( $140 \mathrm{IN}$ per liter), i.e. a complete suppression of homogeneous freezing within the clouds. Considering the IN concentrations measured on both 14 and 15 June over the Jungfraujoch at our operating conditions, an eventual updraft of those air parcels to cirrus regime altitudes could have led to a cloud with fewer but larger ice crystals than in a pristine case and therefore affecting the cloud lifetime (faster sedimentation of larger ice crystals).

\subsection{Correlations of IN with mineral dust}

As previously mentioned, some studies (Archuleta et al., 2005; Welti et al., 2009; Kanji and Abbatt, 2009) showed that the size of mineral dust plays an important role in the ice nucleation efficiency of the particles, and that the larger, the more efficient the particles are. This is confirmed by Mertes et al. (2007) and Kamphus et al. (2010) who found a larger number concentration of larger particles in the ice residuals sampled during CLACE-3 and 6, respectively. As mentioned in Sect 2.3, Schwikowski et al. (1995) showed that the concentration of larger particles is higher during a dust event than for a non SDE event. We investigate a possible correlation between the IN number concentration and the increase in number of larger particles. We used data from the OPC (Grimm Dust monitor 1.108) connected to the total aerosol inlet that counts particles in a size range from $0.3 \mu \mathrm{m}$ to $20 \mu \mathrm{m}$. Due to the use of an impactor connected at the entrance of PINC, we only investigate particle sizes up to $0.6 \mu \mathrm{m}$ during a dust event due to the higher density of dust (see Table 2). The OPC data are also averaged in order to match the time resolution of the IN measurements. Figure 11 shows the IN number concentration as a function of each size class for the two campaigns. Particles of $0.3<$ diameter $(D)<0.5 \mu \mathrm{m}$ show a $R^{2}$ of 0.69 (see Table 3 ) whereas particles of $0.5<D<0.6 \mu \mathrm{m}$ show a better correlation $\left(R^{2}=0.88\right)$ with the IN number concentration. This correlation suggests that the higher concentration of particles larger than $0.5 \mu \mathrm{m}$, the higher IN number concentration 
NOAA HYSPLIT MODEL Backward trajectories ending at 1200 UTC 11 Jun 09 GDAS Meteorological Data

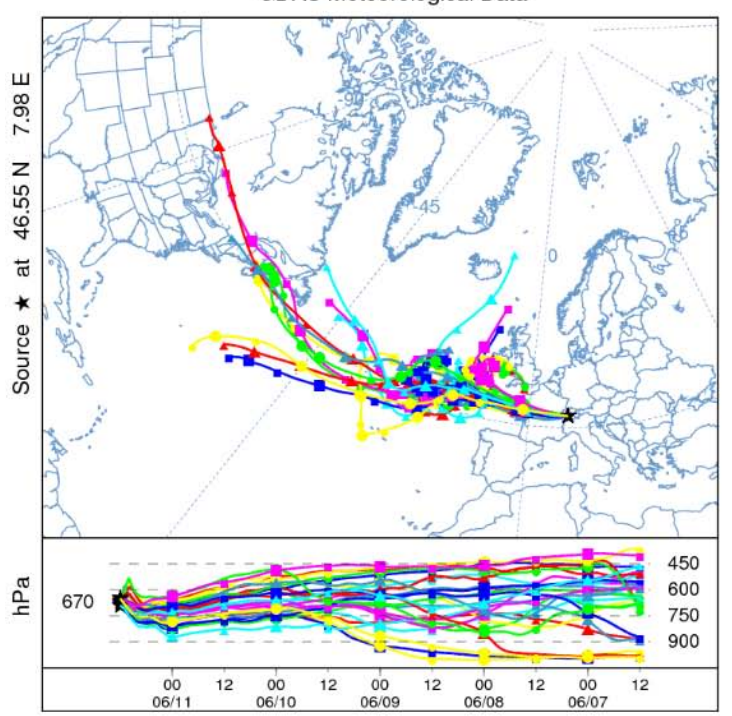

NOAA HYSPLIT MODEL Backward trajectories ending at 1200 UTC 15 Jun 09 GDAS Meteorological Data

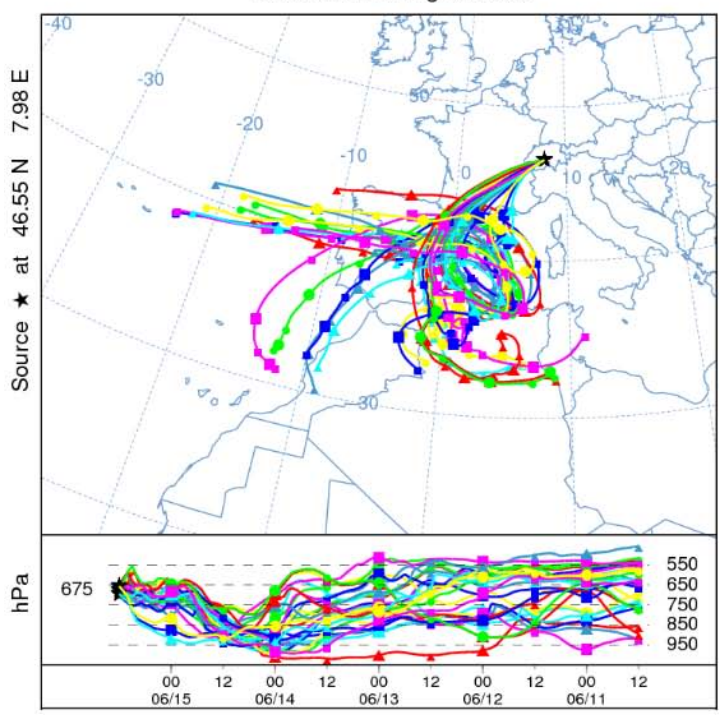

NOAA HYSPLIT MODEL Backward trajectories ending at 1200 UTC 14 Jun 09 GDAS Meteorological Data

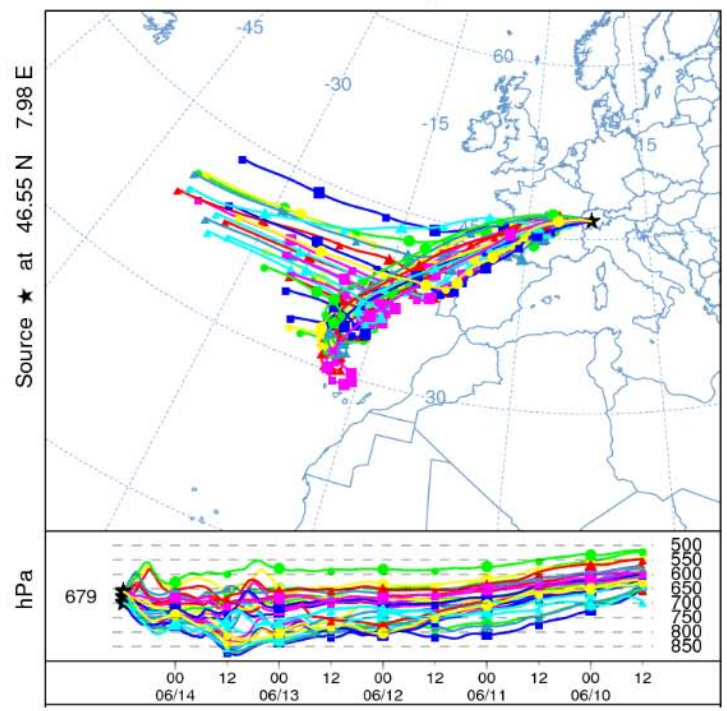

NOAA HYSPLIT MODEL

Backward trajectories ending at 1200 UTC 16 Jun 09 GDAS Meteorological Data

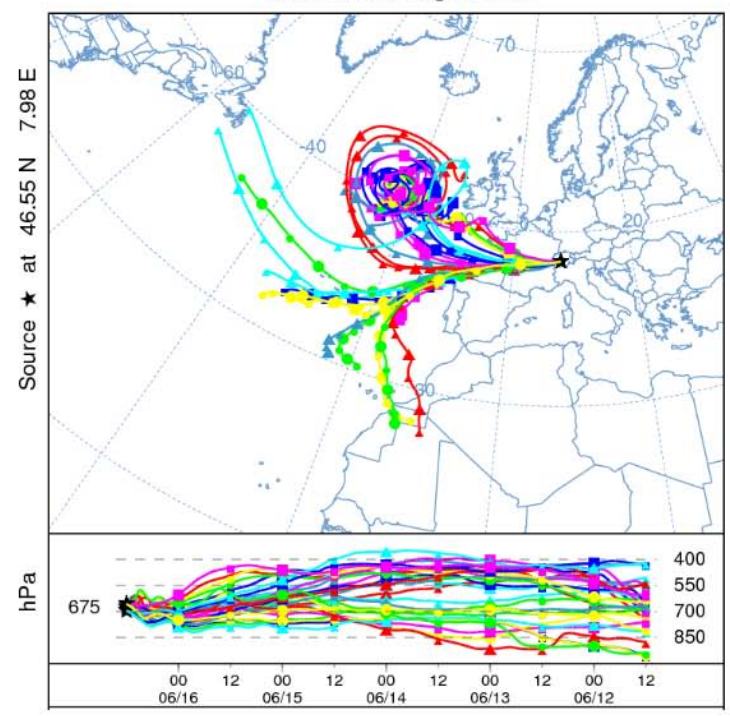

Fig. 10. Four days backtrajectories on 11, 14, 15, and 16 June 2009 at Jungfraujoch at 12:00 p.m. UTC.

we detect. This result is in very good agreement with the parameterization of DeMott et al. (2010) which found a very good correlation between the aerosol number concentration larger than $0.5 \mu \mathrm{m}$ and the number of predicted IN. Note that in their study the IN number concentration was measured at conditions above water saturation where both deposition and condensation nucleation take place whereas we only investigated IN number concentration in the deposition nucleation mode.

\subsection{Correlations of IN with BC}

One of our motivations was to investigate if the formation of ice crystals could have been influenced by the presence of BC. It is important to note that IN are counted as number concentration whereas the $\mathrm{BC}$ concentration is expressed in mass concentrations. We have integrated the $\mathrm{BC}$ mass concentration (derived from the MAAP) over $15 \mathrm{~min}$ to match the time of our IN measurements. During a SDE the absorption coefficient increases due to absorbent compounds found in mineral dust as described in Sect. 2.2. In order to avoid biases due to SDE, and also to assess which other types of 

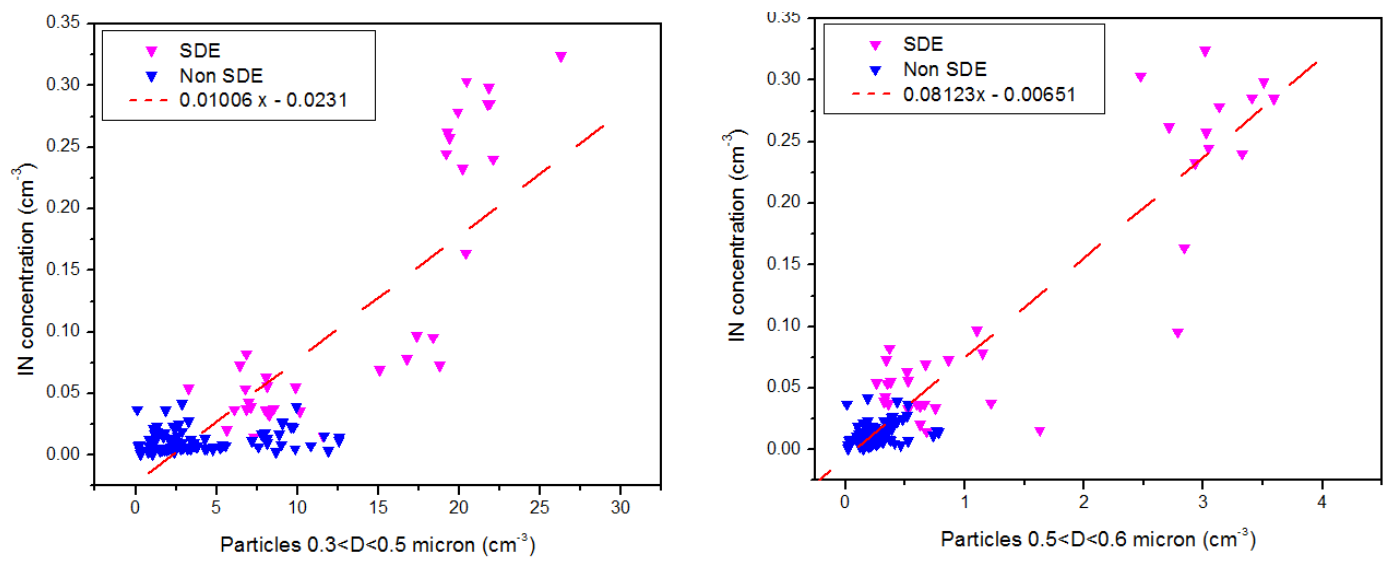

Fig. 11. IN number concentration versus particles number concentration of different size classes: blue triangles represents non SDE measurements and magenta ones, SDE measurements.

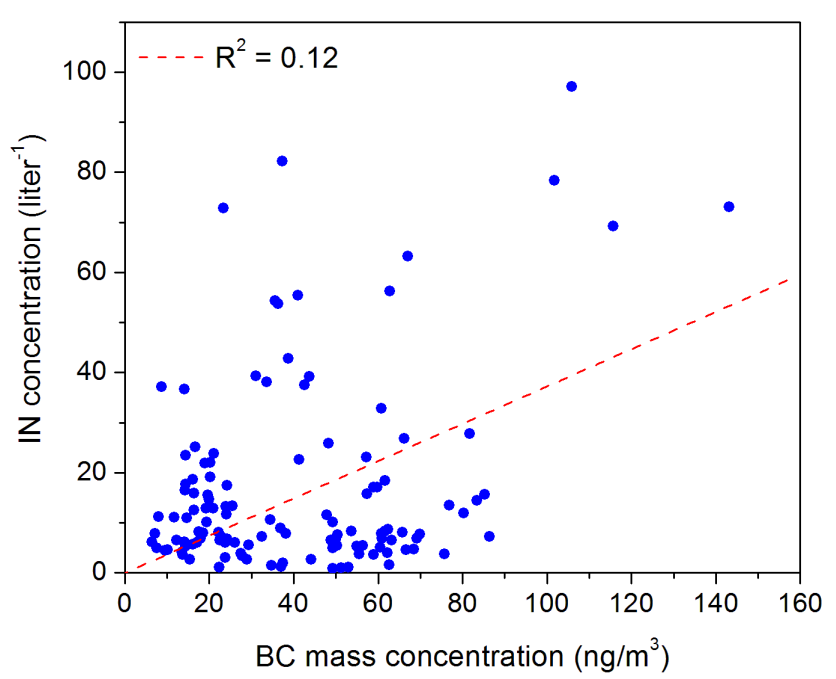

Fig. 12. IN number concentration versus BC concentration during both campaigns on clear days.

particles might act as IN during a non SDE day, we have only investigated the BC dependency on non SDE days as shown in Fig. 12. The $R^{2}$ value between the BC concentration and the IN number concentration is 0.12 . It is thus not possible to conclude that $\mathrm{BC}$ has an impact on the variation of the IN number concentration, although Cozic et al. (2008a) found an enrichment in $\mathrm{BC}$ in the ice residuals measured during three CLACE campaigns. This weak correlation is however in good agreement with the recent study of Kamphus et al. (2010) who found no BC enrichment in the ice residuals during CLACE 6.

\section{Conclusions}

This paper discussed in-situ measurements of IN number concentration and their properties during Saharan dust events (SDE) at the high alpine research station Jungfraujoch (JFJ) at constant thermodynamic conditions of $-31{ }^{\circ} \mathrm{C}, \mathrm{RH}_{\mathrm{i}}$ of $127 \%$ and $\mathrm{RH}_{\mathrm{w}}$ of $91 \%$. It represents the first IN measurements for extended period at the JFJ. We showed that the IN number concentration can increase by one order of magnitude during a SDE, but can also increase by just a factor of 2, suggesting that SDE have different intensities. Future work at the JFJ will require instrumentation that can measure the chemical composition as a function of the size of the particles as was done in the DeMott et al. (2003a) study. We also showed that we have a better correlation between the IN number concentration and the larger aerosol particles (counted by the optical particle counter).

Investigation of the $\mathrm{BC}$ dependence of the IN concentration has been performed as well, and the results showed that there is no correlation between $\mathrm{BC}$ mass concentration and IN number concentration. However this is not conclusive and single particle analysis would be required to see if the ice crystals formed in PINC contain BC. Another important fact is that we worked at conditions where only deposition freezing could take place, meaning that both condensation and immersion freezing onto particles sampled are not investigated. Furthermore, particles larger than $1 \mu \mathrm{m}$ were not entering the chamber, thus reducing the IN number concentration investigated. BC particles could trigger nucleation via immersion or contact freezing which this study did not investigate. Investigation of immersion freezing with the new chamber IMCA developed at our institute (Lüönd et al., 2010) in combination with a Soot Photometer (SP2) could help to investigate the possible role of $\mathrm{BC}$ in future campaigns. 
Acknowledgements. The authors gratefully acknowledge the NOAA Air Resources Laboratory (ARL) for the provision of the HYSPLIT transport and dispersion model and/or READY website (http://www.arl.noaa.gov/ready.php) used in this publication. We would like first to thank Hannes Wydler for all the technical work done on PINC. We would like to thank André Welti, Ana Ćirišan, Vivek Sant and Felix Lüönd for software support. We acknowledge the custodians of the High Alpine Research Station, the Fischer and Seiler. We are also grateful to Mrs Louise Wilson for the organization of the campaigns, and Prof. Dr. Flueckiger for allowing us to perform measurements. We acknowledge the financial support of the Global Atmospheric Watch (GAW) program. Finally we would like to thank the Barcelona Supercomputing Center operator for providing the data and images from the BSC-DREAM8b (Dust REgional Atmospheric Model) model, operated by the Barcelona Supercomputing Center (http://www.bsc.es/projects/earthscience/DREAM/).

Edited by: O. Möhler

\section{References}

Archuleta, C., DeMott, P., and Kreidenweis, S.: Ice nucleation by surrogates for atmospheric mineral dust and mineral dust/sulfate particles at cirrus temperatures, Atmos. Chem. Phys., 5, 26172634, doi:10.5194/acp-5-2617-2005, 2005.

Baltensperger, U., Gäggeler, H., Jost, D., Lugauer, M., Schwikowski, M., Weingartner, E., and Seibert, P.: Aerosol climatology at the high-alpine site Jungfraujoch, Switzerland, J. Geophys. Res.-Atmos., 102(D16) 19707-19715, doi:10.1029/97JD00928, 1997.

Baron, P. and Willeke, K.: Aerosol Measurement: Principles, Techniques, and Applications, Wiley-Interscience, New York, USA, 706-707, 2001.

Braban, C., Abbatt, J., and Cziczo, D.: Deliquescence of ammonium sulfate particles at sub-eutectic temperatures, Geophys. Res. Lett., 28(20), 3879-3882, doi:10.1029/2001GL013175, 2001.

Collaud Coen, M., Weingartner, E., Schaub, D., Hueglin, C., Corrigan, C., Henning, S., Schwikowski, M., and Baltensperger, U.: Saharan dust events at the Jungfraujoch: detection by wavelength dependence of the single scattering albedo and first climatology analysis, Atmos. Chem. Phys., 4, 2465-2480, doi:10.5194/acp4-2465-2004, 2004.

Cozic, J., Verheggen, B., Mertes, S., Connolly, P., Bower, K., Petzold, A., Baltensperger, U., and Weingartner, E.: Scavenging of black carbon in mixed phase clouds at the high alpine site Jungfraujoch, Atmos. Chem. Phys., 7, 1797-1807, doi:10.5194/acp-7-1797-2007, 2007.

Cozic, J., Mertes, S., Verheggen, B., Cziczo, D., Gallavardin, S., Walter, S., Baltensperger, U., and Weingartner, E.: Black carbon enrichment in atmospheric ice particle residuals observed in lower tropospheric mixed phase clouds, J. Geophys. Res, 113, doi:10.1029/2007JD009266, D15209, 2008a.

Cozic, J., Verheggen, B., Weingartner, E., Crosier, J., Bower, K., Flynn, M., Coe, H., Henning, S., Steinbacher, M., Henne, S., et al.: Chemical composition of free tropospheric aerosol for $\mathrm{PM}_{1}$ and coarse mode at the high alpine site Jungfraujoch, At- mos. Chem. Phys., 8, 407-423, doi:10.5194/acp-8-407-2008, 2008b.

DeMott, P.: Laboratory studies of cirrus cloud processes, Cirrus, chapter 5, p. 102, 2002.

DeMott, P., Chen, Y., Kreidenweis, S., Rogers, D., and Sherman, D.: Ice formation by black carbon particles, Geophys. Res. Lett., 26(16), 2429-2432, doi:10.1029/1999GL900580, 1999.

DeMott, P., Cziczo, D., Prenni, A., Murphy, D., Kreidenweis, S., Thomson, D., Borys, R., and Rogers, D.: Measurements of the concentration and composition of nuclei for cirrus formation, Proc. Natl. Acad. Sci. USA, 100, 14655, doi/10.1073/pnas.2532677100, 2003a.

DeMott, P., Sassen, K., Poellot, M., Baumgardner, D., Rogers, D., Brooks, S., Prenni, A., and Kreidenweis, S.: African dust aerosols as atmospheric ice nuclei, Geophys. Res. Lett, 30, 1732, doi:10.1029/2003GL017410, 2003b.

DeMott, P., Prenni, A., Liu, X., Kreidenweis, S., Petters, M., Twohy, C., Richardson, M., Eidhammer, T., and Rogers, D.: Predicting global atmospheric ice nuclei distributions and their impacts on climate, Proc. Natl. Acad. Sci., 107, 11217, doi/10.1073/pnas.0910818107, 2010.

Draxler, R. and Rolph, G.: HYSPLIT (HYbrid Single-Particle Lagrangian Integrated Trajectory) Model access via NOAA ARL READY Website (http://www.arl.noaa.gov/ready/hysplit4.html). NOAA Air Resources Laboratory, Silver Spring, Silver Spring, MD, USA, 2011.

Dymarska, M., Murray, B., Sun, L., Eastwood, M., Knopf, D., and Bertram, A.: Deposition ice nucleation on soot at temperatures relevant for the lower troposphere, J. Geophys. Res.-Atmos., 111, D04204, doi:10.1029/2005JD006627, 2006.

Eastwood, M., Cremel, S., Gehrke, C., Girard, E., and Bertram, A.: Ice nucleation on mineral dust particles: Onset conditions, nucleation rates and contact angles, J. Geophys. Res., 113, D22203, doi:10.1029/2008JD010639, 2008.

Forster, P., Ramaswamy, V., Artaxo, P., Berntsen, T., Betts, R., Fahey, D., Haywood, J., Lean, J., Lowe, D., Myhre, G., Nganga, J., Prinn, R., Raga, G., Schulz, M., and Van Dorland, R.: Changes in atmospheric constituents and in radiative forcing, Clim. Change, 20, 131-217, Cambridge Univ. Press, Cambridge, UK, 2007.

Haywood, J. and Boucher, O.: Estimates of the direct and indirect radiative forcing due to tropospheric aerosols: A review, Rev. Geophys., 38, 513-543, 2000.

Isono, K., Komabayasi, M., and Ono, A.: The nature and origin of ice nuclei in the atmosphere, J. Meteorol. Soc. Jpn., 37, 211-233, 1959.

Kaaden, N., Massling, A., Schladitz, A., Müller, T., Kandler, K., Schütz, L., Weinzierl, B., Petzold, A., Tesche, M., Leinert, S., Deutscher, C., Ebert, E., Weinbruch, S., and Wiedensohler, A.: State of mixing, shape factor, number size distribution, and hygroscopic growth of the Saharan anthropogenic and mineral dust aerosol at Tinfou, Morocco, Tellus, 1600-0889, 2008.

Kamphus, M., Ettner-Mahl, M., Klimach, T., Drewnick, F., Keller, L., Cziczo, D. J., Mertes, S., Borrmann, S., and Curtius, J.: Chemical composition of ambient aerosol, ice residues and cloud droplet residues in mixed-phase clouds: single particle analysis during the Cloud and Aerosol Characterization Experiment (CLACE 6), Atmos. Chem. Phys., 10, 8077-8095, doi:10.5194/acp-10-8077-2010, 2010.

Kanji, Z. and Abbatt, J.: Laboratory studies of ice forma- 
tion via deposition mode nucleation onto mineral dust and nhexane soot samples, J. Geophys. Res.-Atmos., 111, D16204, doi:10.1029/2005JD006766, 2006.

Kanji, Z. and Abbatt, J.: Ice Nucleation onto Arizona Test Dust at Cirrus Temperatures: Effect of Temperature and Aerosol Size on Onset Relative Humidity, J. Phys. Chem., 114(2), 935-941, doi:10.1021/jp908661m, 2009.

Kärcher, B., Hendricks, J., and Lohmann, U.: Physically based parameterization of cirrus cloud formation for use in global atmospheric models, J. Geophys. Res, 111, D01205, doi:10.1029/2005JD006219, 2006.

Klein, H., Nickovic, S., Haunold, W., Bundke, U., Nillius, B., Ebert, M., Weinbruch, S., Schuetz, L., Levin, Z., Barrie, L. A., and Bingemer, H.: Saharan dust and ice nuclei over Central Europe, Atmos. Chem. Phys., 10, 10211-10221, doi:10.5194/acp10-10211-2010, 2010.

Knopf, D. and Koop, T.: Heterogeneous nucleation of ice on surrogates of mineral dust, Journal of geophysical research, 111, D12201, doi:10.1029/2005JD006894, 2006.

Koop, T., Luo, B., Tsias, A., and Peter, T.: Water activity as the determinant for homogeneous ice nucleation in aqueous solutions, Nature, 406, 611-614, 2000.

Kulkarni, G. and Dobbie, S.: Ice nucleation properties of mineral dust particles: determination of onset RHi, IN active fraction, nucleation time-lag, and the effect of active sites on contact angles, Atmos. Chem. Phys., 10, 95-105, doi:10.5194/acp-10-95-2010, 2010.

Lau, K. and Wu, H.: Warm rain processes over tropical oceans and climate implications, Geophys. Res. Lett., 30, 2290, doi:10.1029/2003GL018567, 2003.

Lohmann, U. and Feichter, J.: Global indirect aerosol effects: a review, Atmos. Chem. Phys., 5, 715-737, doi:10.5194/acp-5-7152005, 2005.

Lüönd, F., Stetzer, O., Welti, A., and Lohmann, U.: Experimental study on the ice nucleation ability of size selected kaolinite particles in the immersion mode, J. Geophys. Res., D14201, doi:10.1029/2009JD012959, 2010.

Mangold, A., Wagner, R., Saathoff, H., Schurath, U., Giesemann, C., Ebert, V., Kramer, M., and Mohler, O.: Experimental investigation of ice nucleation by different types of aerosols in the aerosol chamber AIDA: implications to microphysics of cirrus clouds, Meteorol. Zeitsch., 14, 485-497, 2005.

Marcolli, C., Gedamke, S., Peter, T., and Zobrist, B.: Efficiency of immersion mode ice nucleation on surrogates of mineral dust, Nucl. Atmos. Aerosol., 36-40, 2007.

Mason, B. and Maybank, J.: Ice-nucleating properties of some natural mineral dusts, Quarterly J. Roy. Meteorol. Soc., 84, 235-241, 1958.

Mertes, S., Verheggen, B., Walter, S., Connolly, P., Ebert, M., Schneider, J., Bower, K., Cozic, J., Weinbruch, S., Baltensperger, U., et al.: Counterflow virtual impactor based collection of small ice particles in mixed-phase clouds for the physico-chemical characterization of tropospheric ice nuclei: sampler description and first case study, Aerosol Sci. Technol., 41, 848-864, 2007.

Möhler, O., Field, P. R., Connolly, P., Benz, S., Saathoff, H., Schnaiter, M., Wagner, R., Cotton, R., Krämer, M., Mangold, A., and Heymsfield, A. J.: Efficiency of the deposition mode ice nucleation on mineral dust particles, Atmos. Chem. Phys., 6, 3007-3021, doi:10.5194/acp-6-3007-2006, 2006
Möhler, O., DeMott, P., Vali, G., and Levin, Z.: Microbiology and atmospheric processes: the role of biological particles in cloud physics, Biogeosciences, 4, 2559-2591, doi:10.5194/bg-4-25592007, 2007.

Möhler, O., Georgakopoulos, D., Morris, C., Benz, S., Ebert, V., Hunsmann, S., Saathoff, H., Schnaiter, M., and Wagner, R.: Heterogeneous ice nucleation activity of bacteria: new laboratory experiments at simulated cloud conditions, Biogeosciences, 5, 1425-1435, doi:10.5194/bg-5-1425-2008, 2008.

Nickovic, S., Kallos, G., Papadopoulos, A., and Kakaliagou, O.: A model for prediction of desert dust cycle in the atmosphere, J. Geophys. Res., 106(18), 18113-18129, doi:10.1029/2000JD900794, 2001.

Nyeki, S., Li, F., Weingartner, E., Streit, N., Colbeck, I., G "aggeler, H., and Baltensperger, U.: The background aerosol size distribution in the free troposphere: An analysis of the annual cycle at a high-alpine site, J. Geophys. Res., 103, 31749, doi:10.1029/1998JD200029, 1998.

Pérez, C., Nickovic, S., Baldasano, J., Sicard, M., Rocadenbosch, F., and Cachorro, V.: A long Saharan dust event over the western Mediterranean: Lidar, Sun photometer observations, and regional dust modeling, J. Geophys. Res., 111, D15214, doi:10.1029/2005JD006579, 2006a.

Pérez, C., Nickovic, S., Pejanovic, G., Baldasano, J., and Özsoy, E.: Interactive dust-radiation modeling: A step to improve weather forecasts, J. Geophys. Res., 111, D16206, 2006 b.

Petzold, A. and Schönlinner, M.: Multi-angle absorption photometry-a new method for the measurement of aerosol light absorption and atmospheric black carbon, J. Aerosol Sci., 35, 421-441, 2004.

Pratt, K., DeMott, P., French, J., Wang, Z., Westphal, D., Heymsfield, A., Twohy, C., Prenni, A., and Prather, K.: In situ detection of biological particles in cloud ice-crystals, Nat. Geosci., 2, 398401, 2009.

Pruppacher, H. and Klett, J.: Microphysics of Clouds and Precipitation, Reidel, Dordrecht, The Netherlands, 317-321, 1997.

Richardson, M., DeMott, P., Kreidenweis, S., Cziczo, D., Dunlea, E., Jimenez, J., Thomson, D., Ashbaugh, L., Borys, R., Westphal, D., et al.: Measurements of heterogeneous ice nuclei in the western United States in springtime and their relation to aerosol characteristics, J. Geophys. Res., 112, D02209, doi:10.1029/2006JD007500, 2007.

Roberts, P. and Hallett, J.: A laboratory study of the ice nucleating properties of some mineral particulates, Q. J. Roy., Meteorol. Soc., 94, 25-34, 1968.

Rogers, D.: Development of a continuous flow thermal gradient diffusion chamber for ice nucleation studies, Atmos. Res., 22, 149-181, 1988.

Rolph, G.: Real-time Environmental Applications and Display sYstem (READY) Website, available online at: http://ready.arl.noaa. gov/HYSPLIT_traj.php, NOAA Air Resources Laboratory, Silver Spring, Silver Spring, MD, USA, 2011.

Sassen, K.: Indirect climate forcing over the western US from Asian dust storms, Geophys. Res. Lett., 29, 1465, doi:10.1029/2001GL014051, 2002.

Sassen, K., DeMott, P., Prospero, J., and Poellot, M.: Saharan dust storms and indirect aerosol effects on clouds: CRYSTAL-FACE results, Geophys. Res. Lett, 30, 1633, doi:10.1029/2003GL017371, 2003. 
Schaller, R. and Fukuta, N.: Ice nucleation by aerosol particles: Experimental studies using a wedge-shaped ice thermal diffusion chamber, J. Atmos. Sci., 36, 1788-1802, 1979.

Schnell, R. and Vali, G.: Biogenic ice nuclei: Part I. Terrestrial and marine sources., J. Atmos. Sci., 33, 1554-1564, 1976.

Schwikowski, M., Seibert, P., Baltensperger, U., and Gaggeler, H.: A study of an outstanding Saharan dust event at the high-alpine site Jungfraujoch, Switzerland, Atmos. Environ., 29, 1829-1842, 1995.

Spichtinger, P. and Cziczo, D.: Impact of heterogeneous ice nuclei on homogeneous freezing events in cirrus clouds, J. Geophys. Res., 115, D14208, doi:10.1029/2009JD012168, 2010.

Stetzer, O., Baschek, B., Luond, F., and Lohmann, U.: The Zurich Ice Nucleation Chamber (ZINC)-A new instrument to investigate atmospheric ice formation, Aerosol Sci. Technol., 42, 6474, 2008.

Vali, G.: Nucleation terminology, B. Am. Meteorol. Soc., 66, 14261427, 1985.
Vali, G., Christensen, M., Fresh, R., Galyan, E., Maki, L., and Schnell, R.: Biogenic Ice Nuclei. Part II: Bacterial Sources, J. Atmos. Sci., 33, 1565-1570, 1976.

Weingartner, E., Saathoff, H., Schnaiter, M., Streit, N., Bitnar, B., and Baltensperger, U.: Absorption of light by soot particles: determination of the absorption coefficient by means of aethalometers, J. Aerosol Sci., 34, 1445-1463, 2003.

Welti, A., Lüönd, F., Stetzer, O., and Lohmann, U.: Influence of particle size on the ice nucleating ability of mineral dusts, Atmos. Chem. Phys., 9, 6705-6715, doi:10.5194/acp-9-6705-2009, 2009.

Zuberi, B., Bertram, A., Cassa, C., Molina, L., and Molina, M.: Heterogeneous nucleation of ice in (NH4) 2SO4-H2O particles with mineral dust immersions, Geophys. Res. Lett., 29, 1504, doi:10.1029/2001GL014289, 2002. 